\title{
PENGARUH TERPAAN IKLAN PARTAI PERINDO DAN BERITA SEPUTAR PARTAI PERINDO DI TELEVISI TERHADAP PERSEPSI PEMILIH PEMULA MENGENAI PARTAI PERINDO
}

\author{
Reza Muhammad Noor
}

\begin{abstract}
Indonesia is a democratic and multiparty system or system that allows more than two political parties. It is guaranteed in Law No. 2 of 2008 on political parties where it is stated that freedom of association, assembly and expression of thoughts and opinions is a human right recognized and guaranteed by the 1945 Constitution of the Republic of Indonesia. With multiparty system and guarantees of the law, many emerging new political parties in Indonesia. One of them is Partai Persatuan Indonesia or abbreviated as Perindo. The party declared in 2015 is a party formed by Hary Tanoesoedibjo. As a new political party, Perindo Party must have support from the community. Some of the things that are done is to show the party ads and news about the party on television. According to data from the KPU, the largest number of voter-age voters is that the information in advertisements and news about Perindo Party on television is designed in such a way as to appeal to beginner voters. This study aims to determine how much influence the exposure of Perindo Party advertising and exposure of news about the Perindo Party on television to the perception of beginner voters regarding the Perindo Party. Theories used are the Advertising Exposure Theory, Informastion Exposure Theory, and the Uses and Gratification Theory. The population used is Diponegoro University FISIP students who have never participated in the election. While the sample taken is 60 people with purposive sampling method.

Based on the analysis of regression analysis on Perx for Perindo Party Ads on Television (X1), Exposure of News Perindo Party on Television (X2), and Perception of Beginner Voters Regarding Perindo Party (Y), the result of regression coefficient value is $71,3 \%$ significance of Sig value. $=0.000$ which means $>$ significant criterion $(0,05)$, Thus model of regression equation influence of variable $X$ to variable $Y$ is very high and significance between variables based on research data is very significant. Then it shows that there is a strong influence between Perpaan Iklan Perindo Party on Television (X1) and Terpaan Berita Seputar Perindo Party in Television (X2) to Perception of Beginner Voters Regarding Perindo Party (Y). The higher the exposure of Perindo Party advertisement on television and the exposure of Perindo Party news on television, the higher the perception of the beginner voters regarding Perindo Party. It is suggested that the advertising and information designs in the Perindo Party report be improved so that the results are better than now.
\end{abstract}

Keywords: Ad Inclusion, Information, Perception, Beginner Voters, Perindo Party 


\section{PENDAHULUAN}

Pada era demokrasi saat ini, Partai politik adalah salah satu komponen penting bagi kehidupan berbangsa.Dimulai pada tahun 1999 dimana saat itu adalah pertama kalinya rakyat Indonesia memilih secara langsung wakil rakyat.Ruang bagi rakyat untuk berserikat dan berorganisasi juga dijamin oleh perundangundangan dan dalam perkembangannya, banyak muncul Partai politik baru di Indonesia.Salah satunya adalah Partai Perindo.

Partai Persatuan Indonesia atau biasa disingkat Partai Perindo adalah sebuah Partai politik di Indonesia.Partai ini didirikan oleh Hary Tanoesoedibjo, pengusaha dan pemilik MNC Group, sebuah perusahaan yang bergerak dalam bidang media.Perindo di deklarasikan pada 7 Februari 2015 di Jakarta International Expo, Kemayoran, Jakarta. Pada acara deklarasi tersebut, dihadiri oleh beberapa petinggi Koalisi Merah Putih (KMP), seperti Ketua Umum Partai Golkar Aburizal Bakrie, Ketua Umum Partai Amanat Nasional Hatta Rajasa, Presiden Partai Keadilan Sejahtera Anis Matta, dan Ketua Umum Partai Persatuan Pembangunan Djan Faridz. Selain itu juga hadir Wiranto, Ketua Umum Hanura.

Sebagai Partai politik baru, Perindo harus berusaha meningkatkan awareness khalayak di Indonesia. Selain merupakan Partai baru, pada tahun 2018 beberapa daerah di Indonesia akan mengadakan Pilkada serentak sehingga strategi kampanye sudah harus direncanakan sejak saat ini.Kampanye politik adalah usaha terorganisir yang berusaha untuk mempengaruhi prosesproses pembuatan keputusan di dalam kelompok spesifik (Sayuti, 2014: 101).Dalam kehidupan demokrasi tentu tujuannya adalah pemilihan umum.

Terpaan berarti adalah mendengar, melihat, membaca atau yang paling umum adalah mengalami, dengan paling tidak ketertarikan dengan pesan media massa. Terpaan ini bisa terjadi di level individual atau kelompok. Terpaan tidak hanya menyangkut apakah seseorang secara fisik cukup dekat dengan kehadiran media massa, akan tetapi apakah seseorang itu benarbenar terbuka terhadap pesan-pesan media massa tersebut (Kriyantono, 2006: 205).

Exposure merupakan kegiatan mendengar, melihat, dan membaca pesan - pesan media massa ataupun mempunyai pengalaman dan perhatian terhadap pesan tersebut yang terjadi pada individu atau kelompok. Terpaan media menurut Rosengren dapat dioperasionalkan menjadi jumlah waktu yang digunakan dalam berbagai jenis media, isi media yang dikonsumsi, dan berbagai hubungan antara individu konsumen media dengan isi media yang dikonsumsi atau denga media keseluruhan (Rakhmat, 2007: 66). Sedangkan menurut Sari, dapat dioperasionalkan menjadi jenis media yang digunakan, frekuensi penggunaan, maupun durasi penggunaan (Sari dalam Kriyantono, 2006: 205).

Persepsi adalah proses dimana kita mengorganisas dan menafsirkan pola stimulus di dalam lingkungan (Atkinson, 1991). Selain itu persepsi dapat juga diartikan sebagai prosesfisik, fisiologi, dan psikologis yang menyebabkan berbagai macam getaran dan tekanan yang diolah menjadi suatu gambaran tentang lingkungan (Koentjoroningrat dalam Rakhmat, 2007: 70).

Persepsi merupakan pengalaman tentang objek peristiwa atau hubungan yang diperoleh melalui penyimpulan-penyimpulan informasi yang menafsirkan peristiwa. Persepsi menunjuk dua macam proses kerja yang saling berkaitan dengan pembentuknya, yaitu pertama, kesan yang ditangkap melalui panca indera dan yang kedua, penentuan arti melalui penafsiran. Dari pendapat tersebut dapat disimpulkan bahwa persepsi mempengaruhi perilaku dan pembentukan sikap melalui penerimaan stimulus dan penafsiran stimulus tersebut (Rakhmat, 2007: 71).

Faktor-faktor yang mempengaruhi persepsi menurut Baltus (dalam Siregar, 2006:157) adalah: 
1. Kemampuan dan keterbatasan fisik dari alat indera dapat mempengaruhi persepsi untuk sementara waktu ataupun permanen.

2. Kondisi lingkungan.

3. Pengalaman masa lalu. Bagaimana cara individu untuk menginterpretasikan atau bereaksi terhadap suatu stimulus tergantung daripengalaman masalalunya.

4. Kebutuhan dan keinginan. Ketika seorang individu membutuhkan atau menginginkan sesuatu maka ia akan terus berfokus pada hal yang dibutuhkan dan diinginkannya tersebut.

5. Kepercayan, prasangka dan nilai. Individu akan lebih memperhatikan danmenerima orang lain yang memiliki kepercayaan dan nilai yang sama dengannya.

Persepsi adalah pengalaman tentang objek, peristiwa, atau hubungan-hubungan yang diperoleh dengan menyimpulkan informasi dan menafsirkan pesan. (Rakhmat, 2007: 50) Persepsi sendiri merupakan pemberian makna pada stimulus inderawi.Menafsirkan makna informasi inderawi tidak hanya melibatkan sensasi, tetapi juga atensi, ekspektasi, motivasi, dan memori.

Persepsi dipengaruhi oleh faktor personal dan faktor situasional, dan juga perhatian. Menurut Kenneth E. Anderson dalam Psikologi Komunikasi, perhatian terjadi bila kita mengkonsentrasikan diri pada salah satu alat indera kita, dan mengenyampingkan masukanmasukan melalui alat indera yang lain. Dalam variabel persepsi mahasiswa mengenai iklan dan berita mengenai Perindo, yang diukur adalah atensi, ekspektasi, motivasi, dan memori mengenai Perindo.

Adapun permasalahan adalah bagaimanakah pengaruh terpaan iklan Partai Perindo dan berita mengenai Partai Perindo terhadap persepsi pemilih pemula di Kota Semarang mengenai Partai Perindo? Selain itu penelitianinibertujuan untuk mengetahuipengaruh terpaan iklan Partai Perindo dan berita mengenai
Partai Perindo terhadap persepsi pemilih pemula di Kota Semarang.

Di media massa, iklan biasanya berisi mengenai produk yang ingin ditawarkan, entah dalam bentuk barang atau jasa. Dalam penyampaiannya, iklan seringkali tidak secara langsung memaksa penonton dengan kata-kata atau slogan-slogan yang frontal untuk menyampaikan tujuannya. Iklan saat ini sudah menjelma menjadi cara produsen untuk berkomunikasi dengan konsumen melalui pesanpesan yang cerdik dan licin, bukan dengan pesan langsung (Sutherlend dan Sylvester, 2005: 78).

Dengan sifat iklan yang saat ini menyampaikan pesan dengan tidak langsung, maka banyak pengiklan yang mendesain iklannya sedemikian rupa untuk mencapai citra yang diinginkan (Sutherlend dan Sylvestre, 2005: 79). Sebagai contoh iklan produk olahraga, selalu menampilkan seorang atlet besar yang menggunakan produk tersebut untuk kegiatan keolahragaan, dan sama sekali tidak ada pesan frontal untuk menggunakan produk tersebut. Sama halnya dengan iklan produk olahraga tadi, berbagai desain iklan yang saat ini ada di televisi dan media massa lainnya hanya menampilkan gambaran mengenai barang atau jasa yang diiklankan.

Iklan menurut Shimp (2007:240) adalah bentuk komunikasi berbayar dan melalui mediadari sebuah sumber yang bisa diidentifikasi, didesain untuk memengaruhi penerima agar melakukan tindakan, sekarang maupun dimasa depan. Ciri khas berbayar inilah yang membedakan iklan dengan kegiatan marketing communication lainnya.

Kemudian menurut Sutisna (2002:277), tiga tujuan utama periklanan yaitu menginformasikan, membujuk, dan mengingatkan. Shimp $(2003: 357)$ juga menyebutkan fungsiiklan diantaranya memberikan informasi, membujuk pelanggan untuk mencoba produk dan jasayang diiklankan (persuading), 
menjaga agar merek perusahaan tetap segar dalam ingatankonsumen (reminding), memberikan nilai tambah bagi penawaran mereka (adding value), dansebagai alat bantu bagi bauran komunikasi pemasaran lainnya.

Sementara itu, terpaan (exposure) menurut Shimp (2003:69) mengacu pada kesanterhadap iklan. Audiens yang melihat maupun mendengarkan iklan akan memiliki kesan terhadap apa yang mereka lihat atau dengar. Kesan tersebut bisa berupa informasi maupunberbagai hal, seperti tagline dan penghargaan yang diterima perusahaan, yang dicantumkan yangmereka tangkap dalam suatu iklan. Pada dasarnya terpaan ialah interaksi konsumen dengan pesan dari pemasar (Schimp,2003:182). Terpaan merupakan tahap awal yang penting menuju tahap-tahap selanjutnya dari proses informasi. Berdasarkan teori advertising exposure(Batra, Myers, and Aaker,1996: 89) apabila konsumen terkena terpaan iklan maka akan tercipta perasaan dan sikap tertentu terhadap merek yang kemudian akan menggerakan konsumen untuk membeli produk. Khalayak media yang merupakan calon konsumen dari produk yang diiklankan akan mengingat hal-hal yang digambarkan dalam iklan (Sutherlend dan Sylvestre, 2005: 86).

Menurut Wilbur Schramm (Rakhmat, 2007:223) informasi adalah segala sesuatu yang mengurangi ketidakpastian atau mengurangi jumlah kemungkinan alternatif dalam situasi. Informasi membuat realitas tidak bisa dilihat secara murni tetapi memiliki struktur berdasarkan informasi yang kita dapat dan lazimnya disebut citra. Menurut Roberts (Rakhmat, 2007 :223) citra adalah keseluruhan informasi tentang dunia ini yang telah diolah, diorganisir, dan disimpan individu. Dapat dikatakan jika citraadalah bagaimana kita melihat dunia sekitar kita setelah kita mendapatkan beragam infromasi. Peran media massa sangat penting dalam proses ini. Menurut MC Luhann (Rakhmat, 2007 :224) media massa adalah perpanjangan indera manusia yang memungkinkan manusia untuk mengetahui peristiwa, tokoh, atau kejadian tanpa harus berinteraksi langsung.

Salah satu fungsi media massa yang paling penting adalah fungsi informasi. Komponen penting dalam fungsi informasi ini adalah berita, dan iklan yang saat ini telah berkembang sedemikian rupa hingga memuat informasiimformasi di dalamnya. Media massa menyajikan informasi yang disusun berdasarkan fakta-fakta yangtelah dikumpulkan oleh wartawan.

Kejadian atau fakta adalah sebuah hal yang objektif, namun bagaimana kemudian suuatu informasi dipilih dan dikaporkan adalah sesuatu yang subjektif. hal itu sangat bergantung pada gatekeeper yang mengatur manakah informasi yang dianggap penting bagi khalayak. Seperti yang dikemukakan oleh Maxwell McCombs dan Donald L. Shaw (Nurudin, 2011: 195) bahwa pada pemilihan presiden Amerika Serikat, ditemukan hubungan yang tinggi antara penekanan berita dengan bagaimana berita itu dinilai tingkatannya oleh pemilih. Hal ini menunjukkan informasi yang dianggap penting dan disampaikan oleh media massa akan dianggap penting oleh khalayak. Media massa memang tidak memiliki kemapuan untuk mengatur bagaimana kita berpikir, tetapi media massa mampu mengatur apa yang harus kita pikirkan.

Teori yang pertama kali dikemukakan oleh Blumer dan Kaltz ini mengatakan bahwa pengguna media memainkan peran aktif untuk memilih dan menggunakan media tersebut. Berbeda dengan teori Agenda Setting dimana media memberikan informasi tanpa peran aktif dari konsumen media, dalam teori Uses and Gratification ini khalayak media berperan aktif dalam menentukan informasi mana yang akan dikonsumsi, artinya teori uses and gratification mengasumsikan bahwa khalayak media mempunyai pilihan alternatif untuk memuaskan kebutuhannya (Nurudin, 2011: 191). 


\section{Definisi Konseptual dan Operasional}

\section{Definisi Konseptual}

a. Terpaan iklan dan beritaPartai Perindo merupakan bagian mendengarkan, melihat, dan membaca pesan media massa ataupun memiliki pengalaman dan perhatian terhadap iklan politik dan beritaPartai Perindo.

b. Persepsi pemilih pemula terhadap Partai Perindo adalah pengalaman tentang objek, peristiwa, atau hubungan-hubungan yang diperoleh oleh konsumen media dengan menyimpulkan informasi dan menafsirkan pesan dari semua informasi yang diterima tentang Partai Perindo.

\section{Definisi Operasional}

Terpaan iklan Partai Perindo:

- Frekuensi melihat iklan Partai Perindo di Televisi yaitu seberapa sering seseorang melihat iklan Partai Perindo di Televisi.

- Intensitas melihat iklan Partai Perindo yaitu berapa kali seseorang melihat iklan Partai Perindo di Televisi.

- Durasi melihat tayangan iklan Partai Perindo yaitu berapa lama dalam satu hari menonton iklan Partai Perindo.

- Kemampuan untuk menyebutkan tagline Partai Perindo.

- Kemampuan menyebutkan beberapa versi iklan Partai Perindo.

Terpaan Berita Partai Perindo:

- Frekuensi melihat berita tentang Partai Perindo yaitu seberapa sering seseorang melihat berita tentang Partai Perindo.

Intensitas melihat berita tentang Partai Perindo yaitu seberapajauh seseorang mencari tahu berita tentang Partai Perindo.

- Durasi melihat berita tentang Partai Perindo yaitu konsumsi berita tentang Partai Perindo ketika disiarkan.
Persepsi pemilih pemula tentang Partai Perindo:

Adalah proses yang digunakan oleh seorang individu untuk memilih, mengorganisasi, dan menginterpretasi masukan-masukan informasi guna menciptakan gambaran tentang produk, dalam hal ini Partai Perindo sebagai partai politik yang merepresentasikan masyarakat. Persepsi masayarakat mengenai Partai Perindo dapat diukur dengan indikator sebagai berikut :

a. Penerimaan yaitu proses dimana responden menerima informasi mengenai iklan dan berita Partai Perindo.

b. Atensi yaitu perhatian responden terhadap iklan dan berita yang menyangkut Partai Perindo.

c. Ketertarikan yaitu doronganyang muncul untuk memperoleh informasi tentang Partai Perindo baik dari dalam diri sendiri atau dari orang lain.

d. Penilaian yaitu individu membandingkan pengertian atau pemahaman yang baru diperoleh tersebut dengan kriteria atau norma yang dimiliki responden secara subjektif.

e. Harapan yaitu kondisi ideal menurut subjektivitas responden.

Berdasarkan hasil pengujian validitas terpaan iklan Partai Perindo di televisi dinyatakan valid. Terbukti dengan semua nilai hasil r hitung pada indikator variabel yang ditunjukkan dengan nilai Corrected Item Total Correlation tersebut melebihi nilai r hitung yang diperoleh dari nilai $\mathrm{df}$ $=\mathrm{n}-2,60-2=58$, dan á $=0,05$ yaitu 0,254 . Maka, 6 pertanyaan mengenai terpaan iklan Partai Perindo di televisi dapat menjadi acuan dalam mengukur variabel tersebut.

Selain itu hasil pengujian validitas terpaan berita seputar Partai Perindo di Televisi dinyatakan valid. Terbukti dengan semua nilai hasil rhitung pada indikator variabel yang ditunjukkan dengan nilai Corrected Item Total Correlation tersebut melebihi nilai $r$ hitung yang diperoleh dari nilai $\mathrm{df}=\mathrm{n}-2,60-2=58$, dan á $=0,05$ yaitu 
0,254. Maka, 5 pertanyaan di atas dapat menjadi acuan dalam mengukur variabel terpaan berita seputar Partai Perindo di Televisi.

Berdasarkan tabel diatas, hasil pengujian validitas persepsi pemilih pemula mengenai Partai Perindo dinyatakan valid. Terbukti dengan semua nilai hasil $r$ hitung pada indikator variabel yang ditunjukkan dengan nilai Corrected Item Total Correlation tersebut melebihi nilai $r$ hitung yang diperoleh dari nilai $\mathrm{df}=\mathrm{n}-2,60-2=58$, dan á $=0,05$ yaitu 0,254 . Maka, 21 pertanyaan di atas dapat menjadi acuan dalam mengukur variabel persepsi pemilih pemula mengenai Partai Perindo.

Berdasarkan uji analisis regresi terhadap variabel Terpaan Iklan Partai Perindo di Televisi (X1), Terpaan Berita SeputarPartai Perindo di Televisi (X2), dan Persepsi Pemilih Pemula
Mengenai Partai Perindo(Y)didapatkan hasilnilai koefisien determinasi regresi sebesar 71,3\% dengan signifikansi sebesar nilai Sig. $=0,000$ yang berarti $>$ kriteria signifikan $(0,05)$, Dengan demikian model persamaan regresi pengaruh variabel $X$ terhadap variabel $Y$ amat tinggi dan signifikansi antar variabel berdasarkan data penelitian adalah sangat signifikan. Hasil pengujian menunjukkan bahwa hipotesis yang diajukan dalam penelitian ini terbukti karena terdapat pengaruh kuat antara Terpaan Iklan Partai Perindo di Televisi (X1) dan Terpaan Berita Seputar Partai Perindo di Televisi (X2) terhadap Persepsi Pemilih Pemula Mengenai Partai Perindo (Y). Sehingga dapat disimpulkan bahwa setiap peningkatan terpaan iklan Partai Perindo di televisi maka persepsi pemilih pemula mengenai Partai Perindo juga meningkat. 


\section{DAFTAR PUSTAKA}

\section{Buku}

Aaker, David, Rajeev Bartra dan John Myers. 1996. Advertising Management. Fift Edition. New Jersey: Prentice Hall.

Afifudin dan Beni Ahmad Saebani. 2009. Metodologi Penelitian Kualitatif. Bandung: Pustaka Setia.

Atkinson, R. L. (1991). Pengantar Psikologi 2 (Terjemahan: Nurdjannah). Jakarta: Erlangga.

Chaplin, J. P. (1999). Kamus Lengkap Psikologi. penerjemah : Kartini Kartono. Jakarta : PT Raja Grafindo Persada. Faisal Y. 2003.

Cohen. 2007. Research Methods in Education. New York: Routhledge.

Danim, Sudarwan. (2004). Motivasi, Kepemimpinan, dan Efektivitas Kelompok. Jakarta: PT Rineka Cipta.

Kotler, Philip. 2002. Manajemen Pemasaran. Jakarta: Perhallindo.

Kriyantono, Rachmat. 2006. Teknik Praktis Riset Komunikasi. Jakarta: Kencana Prenada Media Group.

Mahmud. 2011. Metode Penelitian Pendidikan. Bandung: Pustaka Setia.

Morley. (1995). Pemilihan dan Pengembangan Media Video Pembelajaran. Jakarta: Grafindo Pers.

Mulyana, Deddy. 2014. Komunikasi Politik: Membedah Visi dan Gaya Komunikasi Praktisi Politik. Bandung: Remaja Rosdakarya.

Nurudin. 2011. Pengantar Komunikasi Massa. Jakarta: PT Raja Grafindo Persada

Purwanto. 2008. Metodologi Penelitian Kuantitatif. Yogyakarta: Pustaka Pelajar.

Rakhmat, Jalaludin. 2007. Psikologi Komunikasi. Bandung: PT Remaja Rosdakarya.

Sayuti, Dulah. 2014. Komunikasi Pemasaran Politik. Bandung: Remaja Rosdakarya.

Silalahi, Ulber. 2015. Penelitian Sosial Kuantitatif. Bandung: Refika Aditama.

Sutisna.2002. Perilaku Konsumen \& Komunikasi Pemasaran.Bandung: Remaja Rosdakarya.

Terence, Schimp. 2003. Periklanan Promosi. Jakarta: Erlangga. 


\section{Internet}

http://www.nielsen.com/id/, diakses pada tanggal 20 Agustus 2017

https://www.youtube.com/watch?v=EKIf_GzgkKI, diakses pada 31Oktober 2017

https://www.youtube.com/watch?v=THaJgpYehmk, diakses pada 31 Oktober 2017

https://www.youtube.com/watch?v=6QILddbUBE, diakses pada 31 Oktober 2017

https://www.youtube.com/watch?v=Cge22YPMQ-A, diakses pada 31 Oktober 2017

https://www.youtube.com/watch?v=Cq7EZvBI4W0, diakses pada 31 Oktober 2107

https://www.youtube.com/watch? $\mathrm{v}=\mathrm{aTzcvSr} 1 \mathrm{mU} 4$, diakses pada 31 Oktober 2017 